○特集 境界領域シンポジウム「ナノ粒子表面物性に基づいたDDS開発」

\title{
高分子の表面修飾による機能性リポソームの設計
}

\author{
河野健司*・弓場英司 \\ 大阪府立大学大学院 工学研究科 \\ 干 599-8531 大阪府堺市中区学園町 1-1
}

\section{Design of Functional Liposomes Based on Surface Modification with Polymers}

\author{
Kenji Kono* and Eiji Yuba \\ Department of Applied Chemistry, Graduate School of Engineering, Osaka Prefecture University \\ 1-1 Gakuen-cho, Naka-ku, Sakai, Osaka 599-8531, Japan
}

For establishment of safe and effective therapy, carriers that achieve high-precision drug delivery are required. Liposomes are one of the most promising drug delivery systems. To increase usefulness of liposomes as drug delivery systems, we have attempted to provide various functions to liposomes via surface surface modification of liposomes with functional polymers. Functions of polymer-modified liposomes were based on their interactions. Therefore, surface-modification of liposomes with temperature-sensitive polymers can give temperature-responsive liposomes whose drug release is triggered by mild heating. Also, surface modification of liposomes with $\mathrm{pH}-$ sensitive polymers can generate $\mathrm{pH}$-responsive liposomes whose destabilization is induced in weakly acidic environments. In addition, modification with several kinds of polymers with different functions can generate multifunctional liposomes. Here, we describe design, preparation and performance of functional liposomes based on the surface modification with functional polymers, such as temperature-sensitive, $\mathrm{pH}$-sensitive, magnetic resonance-detectable polymers for the production of liposomes for high-precision site-specific delivery and/or intracellular delivery of bioactive molecules.

Key words : liposome $/$ temperature-responsive $/ \mathrm{pH}-$ responsive / surface modification $/$ drug delivery $/$ gene vector $/$ dual-signal-responsive

\section{1.はじめに}

薬物，生理活性分子のキャリアは体内の標的組織 に到達するまでそれらの物質を保持し，そこで放出 することが必要である. また，運搬する物質の特性 や作用機構によっては, 細胞内部のオルガネラまで デリバリーすることも必要となる。このような精度 の高いデリバリーを実現するための有効なアプロー

* Corresponding author

Tel \& Fax: 072-254-9330

E-mail: kono@chem.osakafu-u.ac.jp
チとして，様々な刺激や環境に応答性を示すキャリ アの利用が挙げられる。これまでに様々な刺激や環 境に応答するキャリアの構築が試みられてきたが, 代表的なものとして温度応答性キャリアや $\mathrm{pH}$ 応答性 キャリアを挙げることができる．温度応答性キャリ アは，体外からの標的部位への局所加温によって体 内における機能発現を制御できるため, 標的選択的 なデリバリーが可能になる。また， $\mathrm{pH}$ 応答性キャリ アは, 細胞内部に存在するエンドソームなどの酸性 環境を持つオルガネラで機能発現するため, 細胞内 部へのデリバリーに有効である.

リポソームは，脂質分子からなる小胞体であり， 


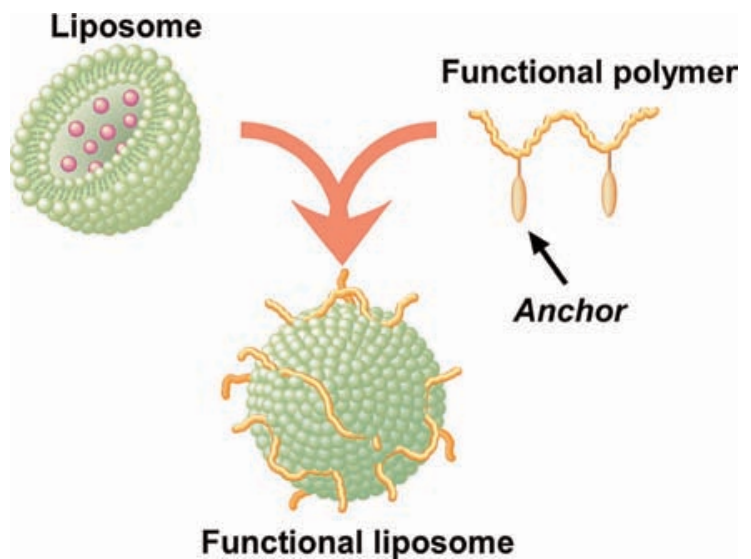

Fig. 1 Design of functional liposomes by surface modification with functional polymers.

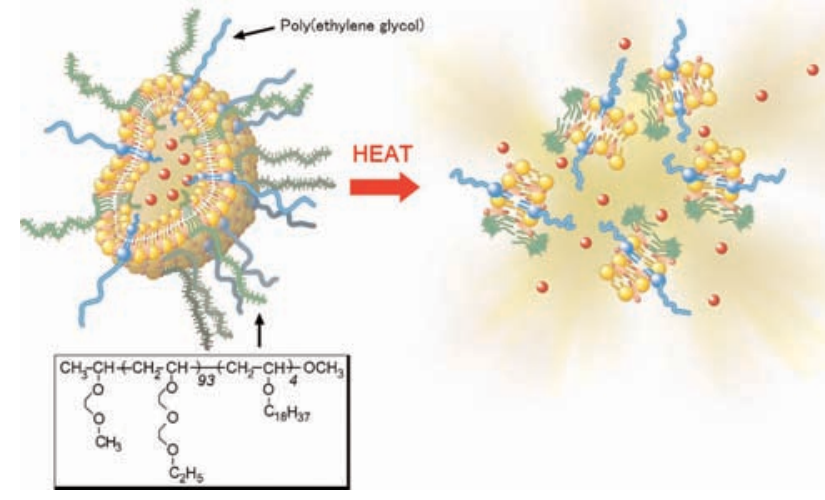

Fig. 2 Design of temperature-responsive liposomes that release antitumor drugs in response to mild heating by surface modification of liposomes with biocompatible poly (ethylene glycol) (PEG) and temperature-sensitive polymers.

ルなど様々なバイオ機能材料に用いられている。こ のような温度応答性高分子をリポソームに複合化す ることによって, それらの刺激に応答するリポソー ムを得ることができる。代表的な温度応答性高分子 であるポリ（N-イソプロピルアクリルアミド）およ びその共重合体をリポソーム表面に固定化すると, 高分子の LCST以上において内包物質の放出が促進さ れる. これは, LCST以上において高分子鎖が疎水性 化するとリポソーム膜を不安定化するためである ${ }^{1)}$.

リポソームの温度応答機能は, 用いる温度応答性 高分子の特性やその固定化の仕方によって影響され る. 例えば，同じ転移温度をもつ $\mathrm{N}$-イソプロピルア クリルアミド共重合でも大きな転移エンタルピーを 示すものほど, 鋭敏な内包物質放出挙動をリポソー ムに与えることができる ${ }^{2)}$. また, 高分子鎖のランダ ムな位置にアンカー部位（長鎖アルキル基など）を 導入してランダムな位置で高分子鎖をリポソームに 固定化した場合に比べて，高分子鎖の末端部分でリ ポソーム膜に固定化した場合，リポソームはよりシ ヤープな温度応答挙動を示す 3 .

温度応答性高分子, ポリ（(2-エトキシ）エトキシ エチルビニルエーテル）は $40{ }^{\circ} \mathrm{C}$ 付近に LCST を示し， 生体適合性高分子であるポリエチレングリコールと 共通構造を側鎖にもつ。この高分子は転移によって 高い疎水性ドメインを形成するため, リポソーム に固定化することによって鋭敏な温度応答性を与え る ${ }^{4)}$. この温度応答性鎖とアンカー部位からなる (2-エトキシ) エトキシエチルビニルエーテルーオク タデシルビニルエーテルブロック共重合体をポリ （エチレングリコール）（PEG）修飾リポソームに複 合化することで鋭敏に温度応答して抗癌剤を放出す 

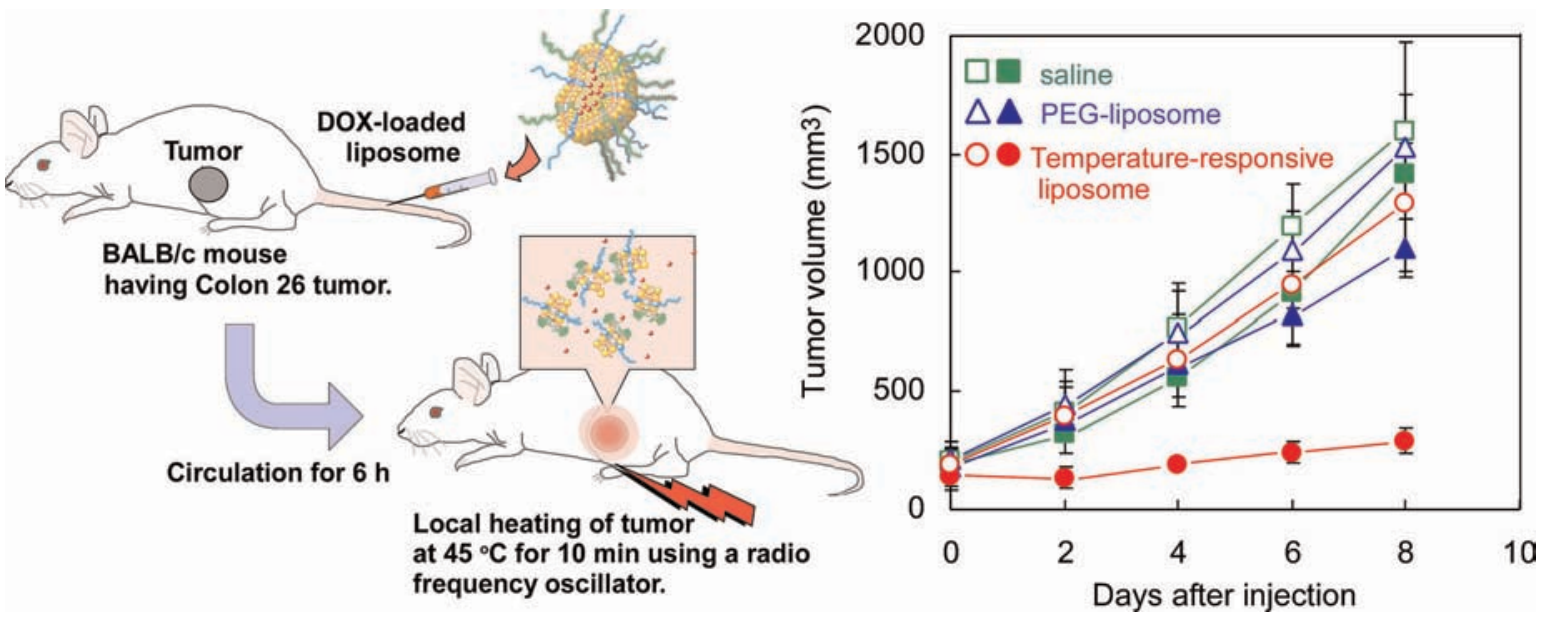

Fig. 3 Tumor growth suppression induced by administration of various liposomes loaded with doxorubicin or saline with (closed symbols) or without (open symbols) heating at $45^{\circ} \mathrm{C}$ for $10 \mathrm{~min}$ at $6 \mathrm{~h}$ after the administration.

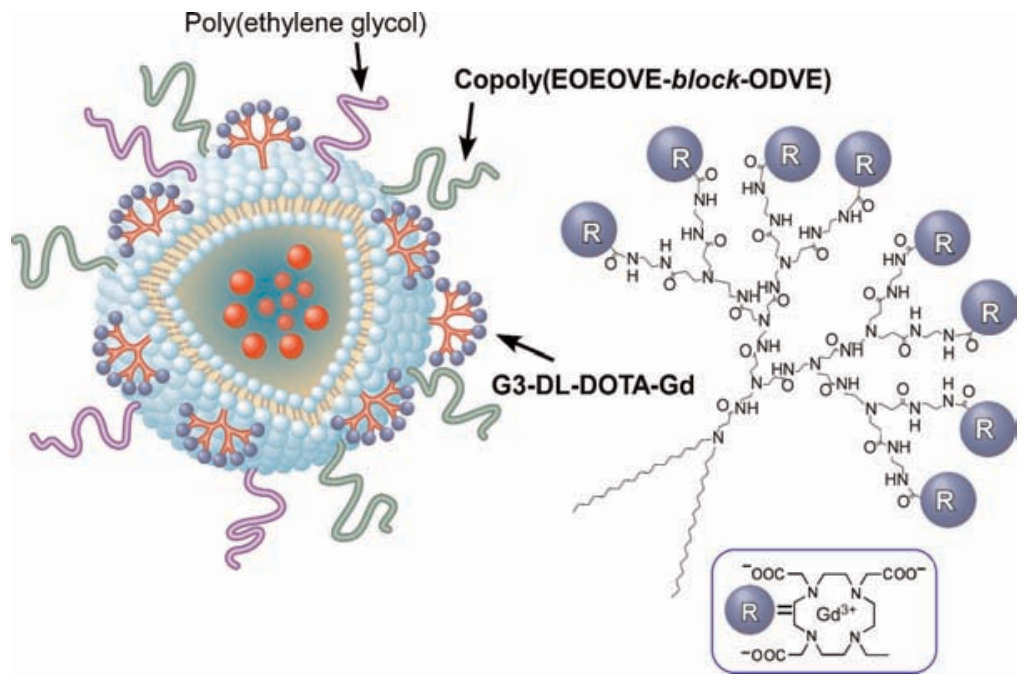

Fig. 4 Design of multifunctional liposome having temperature-controlled drug release and MR detection functions.

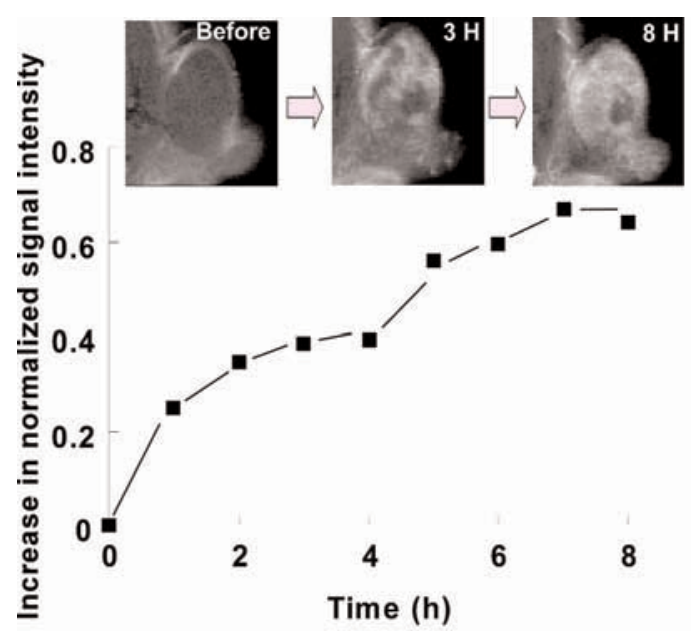

Fig. 5 Detection of tumor accumulation of the multifunctional liposomes using MRI.
るリポソームを開発した (Fig. 2) ${ }^{6}$. このリポソーム は，体温においては抗癌剤ドキソルビシン（DOX） を内包したが， $40^{\circ} \mathrm{C}$ 以上においてその放出が促進さ

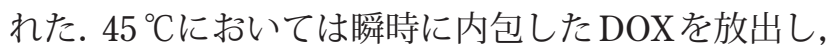
リポソームは高い温度応答性を示した。このリポソ ームを側腹部にColon26細胞腫瘍を移植した担癌マ ウスの尾静脈から投与し，6 時間後に腫瘍病巣を $45^{\circ} \mathrm{C}$ で 10 分間加温すると腫瘍成長が強く抑制された (Fig. 3) ${ }^{6}$. しかし, 同じリポソームを投与しても加 温を行わない場合には，ほとんど腫瘍成長は抑制さ れなかった. 腫瘍部位に集積したリポソームが加温 によって抗がん剂を放出することで高い抗腫瘍効果 が誘起されたものと考えられる.このことは, キャ リアによって抗がん剂が腫瘍部位に到達するだけで なく，その病巣部位において薬物を放出することが
効果的な薬理効果を得るために必要であることを示 している.

\section{3. 温度応答・可視化・多重機能リポソーム}

標的部位におけるリポソームの集積量は時間とと もに変化する。したがって, 温度応答性リポソーム によって効率よく抗癌剂を標的腫瘍部位にデリバリ 一するためには, 生体内におけるリポソームの挙動 をモニターできることが有効であろう. 生体内の現 象を画像化する様々なイメージング技術が知られて いる. 代表的な例として, 核磁気共鳴イメージング (MRI), X 線断層法 ( $\mathrm{X}$ 線 $\mathrm{CT}$ ), 陽電子断層法 (PET)，超音波画像化法などを挙げることができる. なかでも MRI は高解像度の画像を得ることができ, 


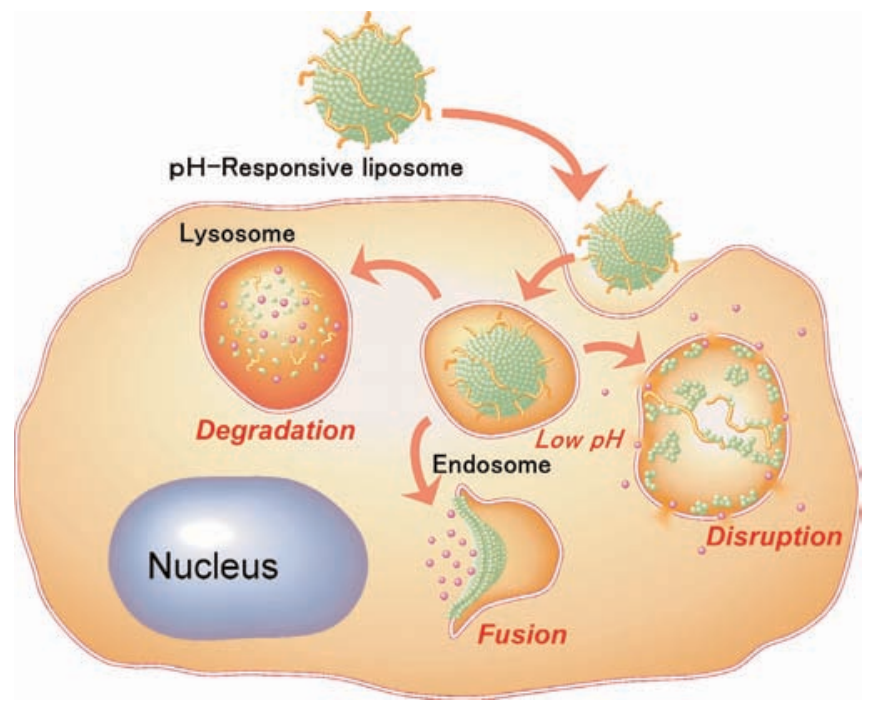

Fig. 6 Mechanism of cytoplasmic delivery mediated by $\mathrm{pH}-$ responsive liposome.

しかも長時間の追跡が可能であることから，キャリ アの可視化のために適した画像化法といえる.

そこで, MRI造影剤であるガドリニウムキレート （DOTA）を結合したデンドロン脂質を合成し，温度 応答性リポソームに組み込んだ (Fig. 4) ${ }^{7}$ )。側腹部に Colon26 細胞腫瘍を移植した担癌マウスにこのリポソ 一ムを投与し，MRIによって腫瘍への集積過程を追 跡したところ, 腫瘍における MRシグナル強度が増 加し，リポソームは時間とともに腫瘍部位に集積す ることが分かった．腫瘍におけるシグナル強度を時 間に対してプロットすることで集積過程を定量的に 評価したところ，8時間程度で集積が最大に達するこ と（Fig. 5), また, リポソームの腫瘍への集積効率 はリポソームの粒径に影響されることがわかった7). また, Fig. 5に示されるように, リポソームは, 腫瘍 に均一に分布するわけではなく, 腫瘍内にリポソー ムが集積していない領域もあることもわかる．さら に, サイズの異なる 2 つ腫瘍をもつ担癌マウスにこ の可視化機能をもつリポソームを投与したところ, サイズの大きな腫瘍に対してより効率よく集積し た ${ }^{7)}$.このことは，たとえ同じ個体内においても腫瘍 の特性は異なることを示唆している．このような可 視化機能をもつリポソームを用いることで, リポソ 一ムによる抗癌剤デリバリーの過程がリアルタイム で追跡できることから, 腫瘍集積量が最大になる最 適のタイミングで加温による抗癌剤放出を誘導する ことで抗癌剤の効果を最大限引き出すことができる. このような体内における情報を発信するキャリアは 患者個人によって異なる病巣に対して的確に対応で きるパーソナルな抗癌剤治療につながるものと期待

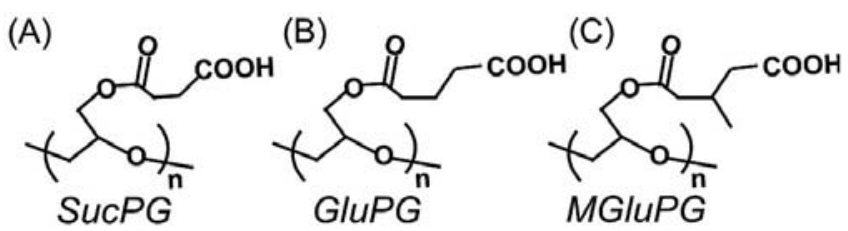

Fig. 7 Structures of $\mathrm{pH}-$ sensitive poly(glycidol) derivatives.

できる.

\section{4. pH 感受性高分子で表面修飾したリポ ソーム}

$\mathrm{pH}$ 応答性リポソームは, 弱酸性 $\mathrm{pH}$ 環境において 不安定化して内包物質を放出したり, 膜融合するリ ポソームである.このようなリポソームは, 種々の 生理活性分子を細胞内部に導入するために用いるこ とができる. Fig. 6 は, pH応答性リポソームによる 細胞内デリバリーの機構を示す。リポソームは主に エンドサイトーシスによって細胞に取り込まれる。 この経路で取り达まれた場合, リポソームはエンド ソームを経てリソゾームで分解される. しかし, $\mathrm{pH}$ 応答性リポソームは, 弱酸性の内部環境をもつエン ドソームにおいて不安定化し, 細胞内部に内包物を 導入する. したがって, $\mathrm{pH}$ 応答性リポソームは細胞 の内部に作用部位をもつタンパク質や核酸医薬, 遺 伝子のキャリアとして有用である.

筆者らは, ポリエチレングリコール類似の主鎖骨 格と側鎖水酸基をもつポリグリシドールをベースと する種々の $\mathrm{pH}$ 応答性高分子（Fig. 7）で卵黄ホスフ アチジルコリンリポソームを表面修飾することによ って弱酸性条件で膜融合する $\mathrm{pH}$ 応答性リポソームを 作製し，その細胞内デリバリー機能について検討し てきた ${ }^{8 \sim 10)}$. これらの $\mathrm{pH}$ 応答性ポリグリシドール 誘導体を複合化したリポソームは中性では安定であ ったが, 弱酸性で不安定化して膜融合能を発現した。 また,リポソームの融合能は側鎖カルボキシル基と 主鎖骨格をつなぐスペーサー部分の疎水性度に依存 し, 疎水性度の高い高分子を複合化したリポソーム ほど強い膜融合機能を発現した. 中でも MGluPGで 修飾したリポソームは, 最も優れた $\mathrm{pH}$ 応答性膜融合 機能を発現した ${ }^{10)}$. これらのリポソームによる HeLa 細胞への蛍光色素カルセインのデリバリーについて 検討した。高分子で修飾していないコントロールリ ポソームとインキュベートした細胞を共焦点蛍光影 微鏡で観察すると, 細胞からは輝点状の蛍光が観察 された。しかし, $\mathrm{pH}$ 応答性高分子で表面修飾したリ 


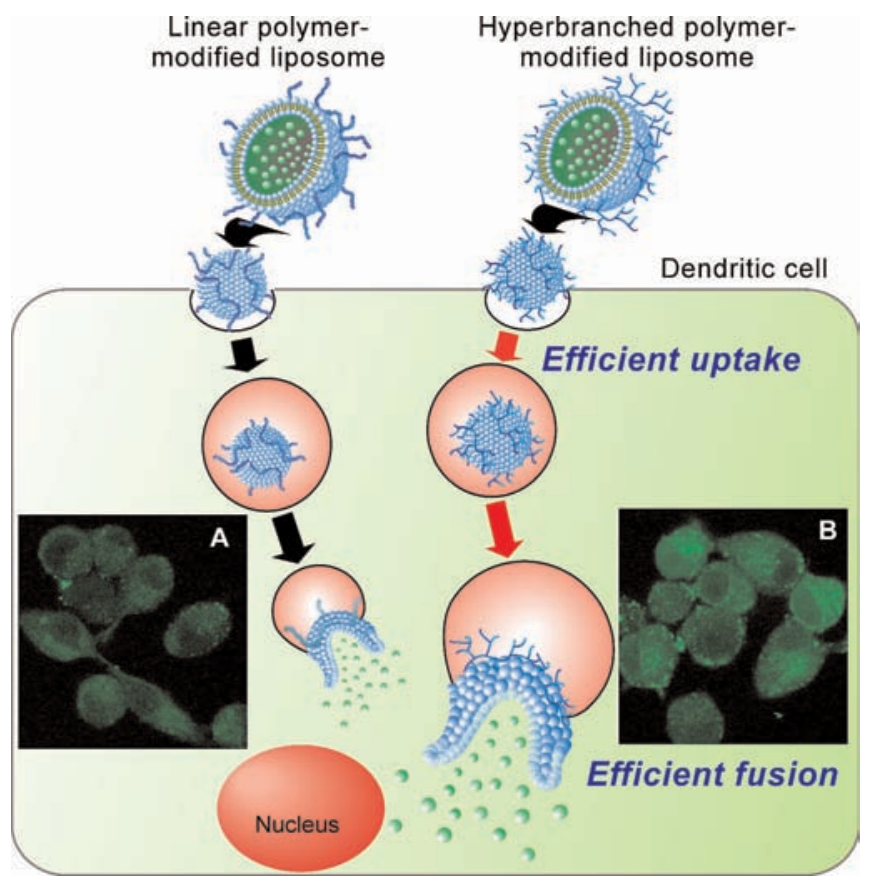

Fig. 8 Cytoplasmic delivery of FITC-labeled ovalbumin into DC2.4 cells mediated by egg lecithin liposomes modified with MGluPG of linear (A) or hyperbranched (B) structure.

ポソームを用いた場合，細胞全体から蛍光が観察さ れた。また，疎水性度の高い側鎖スペーサー部位を もつ高分子で表面修飾したリポソームほど短時間で 細胞内に内包物を導入することが観察された ${ }^{10)}$. 疎 水性度の高い $\mathrm{pH}$ 応答性高分子ほど，微弱酸性におい てエンドソームと強く相互作用して内包物質を細胞 質内に導入できることを示している.

さらに，リポソームの $\mathrm{pH}$ 応答性に及ぼすポリグリ シドールの分子鎖骨格の影響を調べるために，MGlu 化した線状ポリグリシドール（MGluPG）とハイパ ーブランチポリグリシドール（MGluHPG）で修飾し たリポソームを作製し，それらの性能を比較した ${ }^{11}$. その結果, MGluHPG 修飾リポソームはより高い融合 能を示した。 ハイパーブランチポリマーのコンパク トで立体的な分子構造と分子鎖末端の MGlu基が分子 表面に配置されることが高い膜融合機能につながっ たものと思われる ${ }^{11}$ 。これらのリポソームを用いて, FITCでラベル化したオボアルブミン（OVA）のマウ ス樹状細胞株 DC2.4 細胞へのデリバリーを調べた。 Fig. 8に示すように，ハイパーブランチ型の MGluHPGで修飾したリポソームを用いた場合，より 効率よく OVAが細胞内に導入された。 MGluHPG 修 飾リポソームはスキャベンジャーレセプターを介し て効率よく樹状細胞に取り込まれ，また効率よくエ ンドソームと融合することで，OVAを効果的に細胞

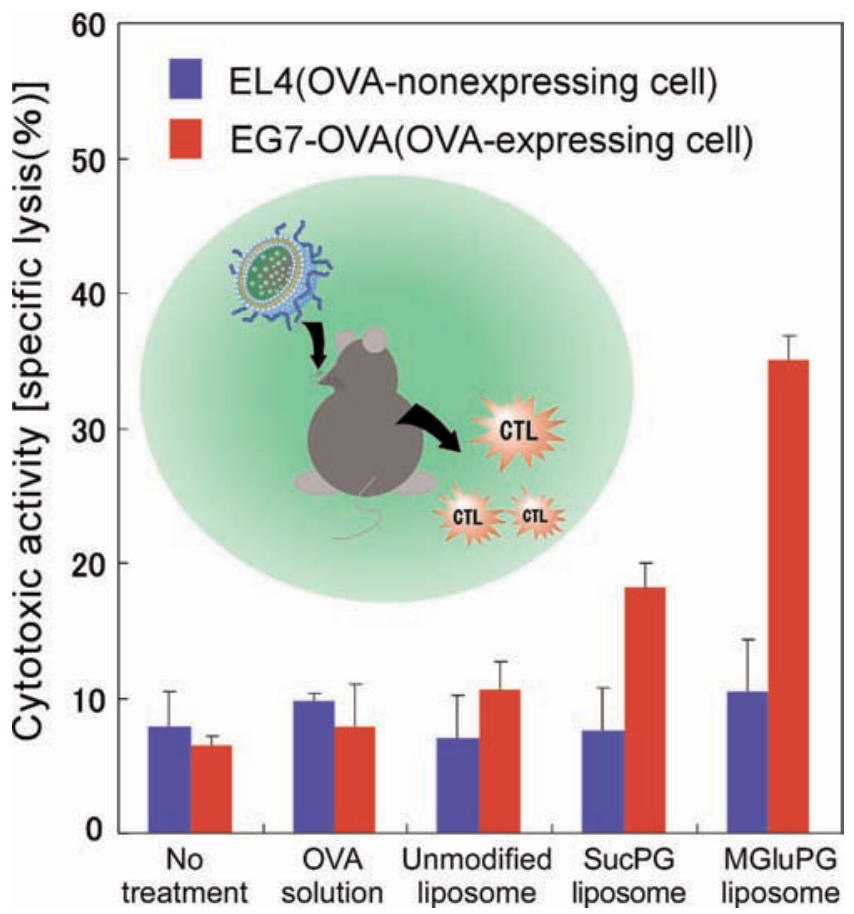

Fig. 9 Induction of OVA-specific cytotoxic T lymphocyte (CTL) by nasal administration of OVA solution and various kinds of OVA-loaded liposomes to mice.

内に導入したものと考えられる ${ }^{11}$.

\section{5. pH 応答性リポソームによる生理活性分子 の細胞内デリバリー}

これらの $\mathrm{pH}$ 応答性リポソームは, エンドソームの 不安定化・融合を介して様々な分子の細胞内への移 行を促進できるため, 細胞内に作用部位をもつ生理 活性分子のデリバリーに応用できる。細胞内部で生 理作用を発現する代表的な分子として siRNA薬やプ ラスミドDNAなどの核酸分子をあげることができ る。これらの分子がその活性を発現するためには， リソゾーム内部における分解を逃れるために, いか に効率よくエンドソームからサイトゾルに移行する かが問題となる. カチオン性脂質は遺伝子と静電的 に結合してリポプレックスとよばれる複合体を形成 するため, 遺伝子導入ベクターとして用いられる。 筆者らは, 正に帯電したリポプレックスに負に帯電 した $\mathrm{pH}$ 応答性高分子修飾リポソームを静電的に結合 させることによってハイブリッド複合体を作製した。 この複合体は負に帯電したリポソームに覆われるた め, 細胞への非特異的な親和性が低下する. しかし, トランスフェリンをリガンドとしたハイブリッド複 合体は, 種々の腫瘍由来細胞 $\left.{ }^{12} \sim 15\right)$ や樹状細胞 ${ }^{16)}$ に 対して高い遺伝子導入活性を示した。さらに, 膜融 


\section{Dual-signal-responsive liposome}

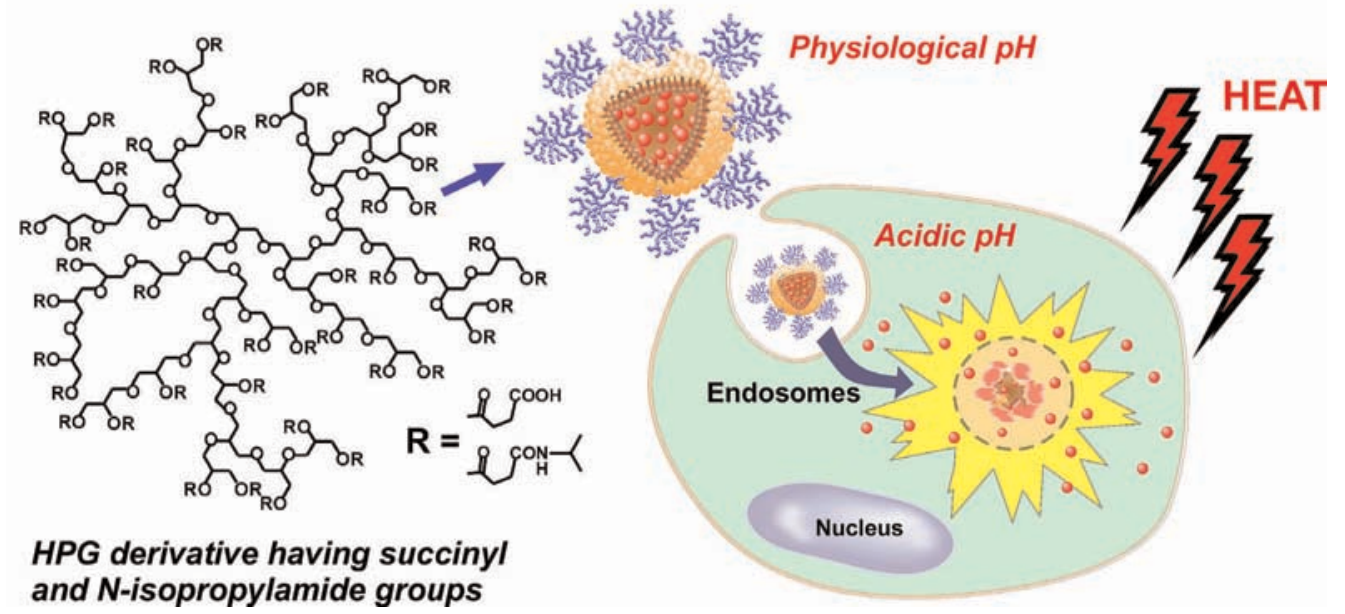

Fig. 10 Design of dual-signal-responsive liposome that releases contents in endosome of a cell in the heated tissues. Liposome was surface-modified temperature-and $\mathrm{pH}$ responsive HPG derivative.

合性の高い $\mathrm{pH}$ 応答性リポソームを用いたハイブリッ ド複合体ほど，より効率よく細胞の遺伝子発現を誘 導した ${ }^{17)}$. このことはエンドソームからサイトゾル への遺伝子の移行を効果的に行うことが遺伝子発現

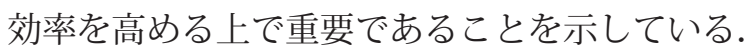

一方, 細胞内部へのデリバリーは, 癌免疫治療に おいても重要である. 免疫の活性化においては，樹 状細胞などの抗原提示細胞に効率よく抗原を導入す ることが必要であるが, 特に癌免疫治療において重 要な役割を果たす抗原特異的な細胞性免疫を活性化 するためには, 抗原提示細胞の細胞質中に抗原を導 入することが必要となる. $\mathrm{pH}$ 応答性リポソームは樹 状細胞への抗原デリバリーシステムとして用いるこ とができる。実際，モデル抗原オボアルブミン （OVA）を封入し SucPG，MGluPG やMGluHPGで修 飾したリポソームを用いることでマウス樹状細胞株 DC2.4 細胞の細胞質内に OVAを効率よく導入でき た ${ }^{11,18)}$.

OVAを封入したSucPG 修飾リポソームや MGluPG 修飾リポソームをマウスに経鼻投与し，その細胞性 免疫の誘導について調べ, OVA内包未修飾リポソー ムやOVA水溶液を投与した場合と比較した（Fig. 9）. OVAを封入した未修飾リポソームやフリーの OVAを 投与した時にはマウスに OVA特異的な細胞障害性 T 細胞（CTL）はほとんど誘導されなかったが， pH応 答性高分子リポソームを投与すると抗原特異的な CTLが誘導されることがわかった．また，SucPG修 飾リポソームに比べて MGluPG 修飾リポソームはよ り効果的な細胞性免疫を誘導した ${ }^{18)}$ 。これらの結果 は, 細胞性免疫を誘導する際には, 膜融合によって 効率よく抗原提示細胞のサイトゾル中に抗原を導入
することが重要であることを示している.

\section{6. デュアルシグナル応答性リポソーム}

筆者らはこれまでに, 温度と $\mathrm{pH}$ のつのシグナル に対して応答性を示す分岐型ポリグリシドール誘導 体を作製した ${ }^{19}$ ．このようなポリマーでリポソーム を表面修飾するとリポソームは $\mathrm{pH}$ と温度に応答性を 示すため, これらの 2 つのグナルによって機能発現 を 2 重制御されるデュアルシグナル応答性リポソーム が構築できる.この高分子はスクシニル基と N-イソ プロピルアミド基をもち, それらの官能基の比率を 調節することで, 弱酸性 $\mathrm{pH}$ で加温されると疎水化す るデュアルシグナル応答性高分子が得られる.この 高分子でリポソームを表面修飾すると, 弱酸性環境 下, 加温時に不安定化するデュアルシグナル応答性 リポソームが得られる (Fig. 10) ${ }^{20)}$. このリポソーム は, エンドサイトーシスで細胞内に取り込まれてエ ンドソーム内部にトラップされ, しかも加温された ときに不安定化して内包物を放出する. 実際, 蛍光 色素ピラニンを内包したデュアルシグナル応答性リ ポソームを HeLa細胞とインキュベートした場合, 細 胞内のエンドソーム内部でのみピラニンの蛍光が観 察されたが，この細胞を短時間加温すると細胞全体 からピラニンの蛍光が観察された. エンドソーム内 部に保持されたリポソームが加温により不安定化し てピラニンを放出し, また同時にエンドソーム膜が 乱され, その結果, ピラニンがサイトゾル中に拡散 したものと考えられる。デュアルシグナル応答性リ ポソームは, 加温された標的部位の細胞内エンドソ ームに取り込まれると内包物をサイトゾル中に放出 
するが，加温されていない部位，あるいは加温され ても細胞外に存在する場合は, 内包物を放出しない 20).したがって，このようなリポソームは，標的組 織の細胞内に効率よく生理活性分子を導入する新し いインテリジェントキャリアとして利用できる.

\section{7. おわりに}

本稿では高分子の表面修飾のアプローチによる機 能性リポソームの設計について述べた，高分子の合 成法は著しく進歩し, 分子量制御, 分岐構造, ブロ ック構造, 未端官能基の導入などの高分子構造制御 がますます厳密に行えるようになってきている。ま た, 合成法の発展は, 高分子の機能設計の自由度を 格段に広め, 多様な機能をもつ高分子化合物の開発 を可能にしている.この高分子の表面修飾のアプロ 一チは多様で優れた機能性をもつリポソーム構築の ための効果的なアプローチである。これからの医療 の発展にとって, 薬物・生理活性分子の精密デリバ リー技術の重要性はますます大きくなる，効果的な 薬物治療を行うためには, 標的病巣において一気に 薬物を放出して作用させたり，あるいは，細胞内部 の作用部位に生理活性分子を送達してその薬理効果 を十分発現させることが必要である．特に siRNAな どの次世代医薬を活用するためには, 標的病巣の細 胞内部まで送り届ける, 高度なデリバリー機能が不 可欠である. また，このような標的細胞内部へ送達 するキャリアは，細胞内分子を標的とする新しい薬 物治療戦略の開拓にもつながる。ささらに,イメージ ング機能を付加した生体内情報発信型キャリアは, 個人対応型の化学治療の実現につながる.このよう な合目的な機能を高い次元で発現する高性能キャリ アによって, 新しい治療技術が開拓されていくこと を期待する.

\section{文献}

1) Kono K: Adv. Drug Delivery Rev., 53, 307 (2001)

2) Yoshino K, Kadowaki A, Takagishi T, Kono K : Bioconjugate Chem., 15, 1102 (2004)

3) Kono K, Nakai R, Morimoto K, Takagishi T : Biochim. Biophys. Acta, 1416, 239 (1999)

4) Aoshima S, Oda H, Kobayashi E : J. Polym. Sci., Part A : Polym. Chem., 30, 2407 (1992)

5) Kono K, Murakami T, Yoshida T, Haba Y, Kanaoka S, Takagishi T, Aoshima S : Bioconjugate Chem., 16, 1367 (2005)

6) Kono K, Ozawa T, Yoshida T, Ozaki F, Ishizaka Y, Maruyama K, Kojima C, Harada A, Aoshima S : Biomaterials, 31, 7096 (2010)
7) Kono K, Nakashima S, Kokuryo D, Aoki I, Shimomoto H, Aoshima S, Maruyama K, Yuba E, Kojima C, Harada A, Ishizaka Y : Biomaterials, 32, 1387 (2011)

8) Kono K, Zenitani K, Takagishi T : Biochim. Biophys. Acta, 1 193, 1 (1994)

9) Kono K, Igawa T, Takagishi T : Biochim. Biophys. Acta, 1325, 143 (1997)

10) Sakaguchi N, Kojima C, Harada A, Kono K : Bioconjugate Chem., 19, 1040 (2008)

11) Yuba E, Harada A, Sakanishi Y, Kono K : J. Control. Release, 149, 72 (2011)

12) Kono K, Torikoshi Y, Mitsutomi M, Itoh T, Emi N, Yanagie H, Takagishi T: Gene Therapy, 8, 5 (2001)

13) Sakaguchi N, Kojima C, Harada A, Koiwai K, Shimizu K, Emi N, Kono K : Int. J. Pharm., 325, 186 (2006)

14) Sakaguchi N, Kojima C, Harada A, Koiwai K, Emi N, Kono K : Bioconjugate Chem., 19, 1588 (2008)

15) Sakaguchi N, Kojima C, Harada A, Koiwai K, Shimizu K, Emi N, Kono K : Biomaterials, 29, 1262 (2008)

16) Yuba E, Kojima C, Sakaguchi N, Harada A, Koiwai K, Kono K : J. Control. Release, 130, 77 (2008)

17) Sakaguchi N, Kojima C, Harada A, Koiwai K, Kono K : Biomaterials, 29, 4029 (2008)

18) Yuba E, Kojima C, Harada A, Tana, Watarai S, Kono K : Biomaterials, 31, 943 (2010)

19) Kojima C, Yoshimura K, Harada A, Sakanishi $Y$, Kono K : Bioconjugate Chem., 20, 1054 (2009)

20) Kaiden T, Yuba E, Harada A, Sakanishi Y, Kono K : Bioconjugate Chem., submitted.

(Received 16 June 2011;

Accepted 17 June 2011)

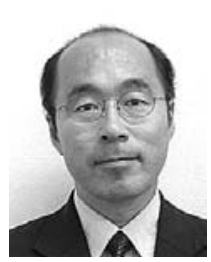

$\begin{array}{ll}\text { 著者略歴 } & \\ \text { 河野 健司（こうの けんじ） } \\ 1984 \text { 年 } 3 \text { 月 } & \text { 京都大学工学部高分 } \\ & \text { 子化学科卒業 } \\ \text { 1986年 } 3 \text { 月 } & \text { 京都大学大学院工学 } \\ & \text { 研究科高分子化学専 } \\ & \text { 攻修士課程卒業 } \\ & \text { 京都大学大学院工学 } \\ & \text { 研究科高分子化学専 } \\ & \text { 攻博士後期課程研究 } \\ & \text { 指導認定退学 } \\ \text { 1989年 } 3 \text { 年 } 4 \text { 月 } & \text { 大阪府立大学工学部 } \\ & \text { 応用化学科 助手 } \\ 1990 \text { 年 } 1 \text { 月 } & \text { 工 学 博 士 (京 都 } \\ & \text { 大学) } \\ \text { 1994年 } 4 \text { 月 } & \text { 大阪府立大学工学部 } \\ & \text { 機 能 物 質 科 学 科 } \\ & \text { 講師 } \\ & \text { 大阪府立大学工学部 } \\ & \text { 機能物質科学科 助 } \\ & \text { 教授 }\end{array}$


1997 年 6 月〜 1998 年 5 月 カリフ オルニア大学バーク レイ校客員研究員, Frechet研究室, デ ンドリマーのDDS への応用）

2002 年 4 月 大阪府立大学大学院 工学研究科機能物質 科学分野 教授

2005 年 4 月 大阪府立大学大学院 工学研究科応用化学 分野 教授

現在に至る.

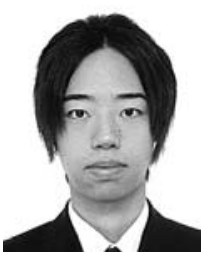

弓場 英司（ゆば えいじ）

2006 年 3 月 大阪府立大学 工学 部 機能物質科学科 卒業

2009 年 4 月～ 2010 年 3 月 日本学 術振興会 特別研 究員

2010 年 3 月 大阪府立大学大学院 工学研究科応用化学 分野博士後期課程 短期修了（博士 (工学))

2010 年 4 月 大阪府立大学大学院 工学研究科応用化学 分野 助教 